\title{
Cardiac injury in severe head trauma, incidence and outcome
}

\author{
A Hasanin ${ }^{1 *}$, A Kamal $^{1}$, S Mostafa ${ }^{1}$, D Zakaria', R Elsayed ${ }^{2}$, A Mukhtar $^{1}$ \\ From ESICM LIVES 2015 \\ Berlin, Germany. 3-7 October 2015
}

\section{Introduction}

Although cardiac injury was reported in patients with neurosurgical conditions, few data report cardiac injury in patients with traumatic brain injury (TBI) [1].

\section{Objectives}

The aim of this work is to report the incidence of cardiac injury in patients with TBI and its impact on patient outcome.

\section{Methods}

A prospective observational study was conducted on a cohort of 50 patients with severe TBI. Only Patients with isolated severe TBI defined as Glasgow coma scale (GCS) $<8$ were included in the study. APACHE II score, GCS, hemodynamic data, serum Troponin I, electrocardiogram (ECG), and echocardiographic examination, and patients' outcome were recorded. A Cardiac Injury Score (CIS) was calculated for all patients (rising troponin $=1$, abnormal echocardiography $=1$, hypotension $=1$ ), univariate and multivariate analysis for risk factors for mortality was done for all risk factors.

\section{Results}

Among a cohort of 50 patients, age was $31 \pm 12$, APACHE II was $21 \pm 5$, and male patients were 45 (90\%). Troponin I was elevated in $27(54 \%)$ patients, abnormal echocardiography and hypotension were documented in 14(28\%) and 16 (32\%) patients respectively. The in-hospital mortality was $64 \%$. Risk factors for mortality by univariate analysis were; age, GCS, APACHE II score, serum troponin level, CIS, and hypotension. However, in multivariate analysis the only two independent risk factors for mortality; were APACHE II score (OR $=1.25,95 \%$ confidence interval: 1.02-1.54, $\mathrm{P}=0.03$ ) and CIS score

${ }^{1}$ Cairo University, Anesthesia and Critical Care Medicine, Cairo, Egypt

Full list of author information is available at the end of the article
$(\mathrm{OR}=8.38,95 \%$ confidence interval: 1.44-48.74, $\mathrm{P}=$ $0.018)$.

\section{Conclusions}

Cardiac injury is common in patients with TBI and associated with increased mortality. The association of high cardiac injury score and poor outcome in these patients warrants further larger study.

Authors' details

${ }^{1}$ Cairo University, Anesthesia and Critical Care Medicine, Cairo, Egypt. ${ }^{2}$ Cairo

University, Clinical and Chemical Pathology, Cairo, Egypt.

Published: 1 October 2015

Reference

1. Prathep S, Sharma D, Hallman M, Joffe A, Krishnamoorthy $V$, Mackensen GB, et al: Preliminary report on cardiac dysfunction after isolated traumatic brain injury. Crit Care Med 2014, 42(1):142-147.

doi:10.1186/2197-425X-3-S1-A486

Cite this article as: Hasanin et al.: Cardiac injury in severe head trauma, incidence and outcome. Intensive Care Medicine Experimental 2015 3(Suppl 1):A486. (c) 2015 Hasanin et al.; This is an Open Access article distributed under the terms of the Creative Commons Attribution License (http:// creativecommons.org/licenses/by/4.0), which permits unrestricted use, distribution, and reproduction in any medium, provided the original work is properly cited.
Submit your manuscript to a SpringerOpen ${ }^{\circ}$ journal and benefit from:

- Convenient online submission

- Rigorous peer review

- Immediate publication on acceptance

- Open access: articles freely available online

- High visibility within the field

Retaining the copyright to your article

Submit your next manuscript at $>$ springeropen.com 